\title{
Seaweed Biofuel Derived from Integrated Multi-trophic Aquaculture
}

\author{
Amita Jacob, Ao Xia, Daryl Gunning, Gavin Burnell, and Jerry D. Murphy
}

\begin{abstract}
Aquaculture contributed 23.8 million tonnes of aquatic algae globally in 2012. Increasing consumption of seaweed (as food, for the production of hydro-colloids, and for production of third generation biofuels) will lead to an upward trend in its production and cultivation. Aquaculture contributed 66.6 million tonnes of fish in 2012, $42 \%$ of global production. Fish demand globally is rising to meet food and nutritional requirements; aquaculture for fish will grow. However fish farms are marred by criticism of pollution caused by discharge of waste. Integrated multi-trophic aquaculture can reduce pollution through co-culture of several species such as seaweed and mussels that utilise waste disposed from fish farms for their growth and development.

A model is investigated which would provide $1.25 \%$ of energy in transport in the EU from seaweed. This would involve annual production of $168 \mathrm{Mt}$ of seaweed (in excess of present world harvest) integrated with 13Mt of farmed salmon. Themodel proposes 2603 anaerobic digesters, each treating 64,500 t/a of Saccharinalatissima in coastal digesters adjacent to natural gas infrastructure for downstream use in natural gas vehicles.
\end{abstract}

Index Terms-Bio-methane, gaseous biofuel, hydro-colloids, integrated multi-trophic aquaculture, seaweed.

\section{INTRODUCTION}

\section{A. The Market for Seaweed}

Seaweed (macro-algae) is extensively used as a food in several countries including China, Japan and the Republic of Korea. In the last decade seaweeds have been used to produce hydrocolloids in the food processing and cosmetics industry. Recent applications of seaweeds include in the field of bio-catalysis, bio-plastics, pharmacology and textiles. The level of use of seaweed is excessive for natural stocks; hence close to $90 \%$ of the seaweed used today comes from aquaculture [1]. There has been a significant increase in the production of farmed aquatic plants. The FAO reported a production of 15.8 million Tonnes (wet weight) of aquatic plants in 2008 from aquaculture; $99.6 \%$ of this production is seaweed and by 2013 the aquaculture harvest rose to 26.1

Manuscript received October 13, 2015; revised January 13, 2016. This research is funded by the Science Foundation Ireland (SFI) centre MaREI $(12 / \mathrm{RC} / 2302)$. Industrial funding is provided by Gas Networks Ireland through the Green Gas Innovation Group and by ERVIA.

Amita Jacob and Ao Xia are with the Environmental Research Institute, University College Cork, Ireland (e-mail: amitajacob13@gmail.com, ao.xia@ucc.ie).

Daryl Gunning and Gavin Burnell are with the School of Biological, Earth and Environmental Sciences, University College Cork, Ireland (e-mail daryl.gunning@gmail.com, g.burnell@ucc.ie).

Jerry D. Murphy is with the Environmental Research Institute and the School of Engineering, University College Cork, Ireland (e-mail: jerry.murphy@ucc.ie). million tonnes of aquatic plants; again the majority of which is seaweed [2]. This is a $65 \%$ increase in 5 years. The seaweed industry is valued at US\$ 5.5-6 billion annually of which human consumption accounts for US\$ 5 billion [1].

Hydrocolloids are substances, which form gel in water. In the food industry they are used to bind food proteins in the dairy and meat industry. Seaweeds can be a vegetarian substitute for gelatine. The hydrocolloids industry produces alginates, agar and carrageen an from seaweed; this industry was worth US\$ 600 million in 2003 and increased to US\$ 1156 million in 2014 [1]. This is an increase of $92.6 \%$ in 11 years.

\section{B. The Market for Seafood}

By 2050 our planet will be home to close to 9.6 billion people. More food and nutrition will be required. Most importantly an adequate amount of protein will be necessary to prevent malnourishment. Meat protein is increasingly being used as a source of protein but it is unsustainable in the long run as the amount of $\mathrm{CO}_{2}$ released per $\mathrm{kg}$ of edible meat is highest for cattle meat (30 kg CO $2 / \mathrm{kg}$ edible meat) and is the least for farmed fish (29 $\mathrm{kg} \mathrm{CO} / \mathrm{kg}$ edible meat) [3]. Globally around $158 \mathrm{Mt}$ of food fish was produced in 2012 which includes finfish, crustaceans, molluscs, amphibians, sea squirts and edible jellyfish. Aquaculture contributed $42 \%$ to the total production of food fish in 2012; the remainder was supplied by capture production [2]. Protein from fish contributed $16.7 \%$ to the global animal protein intake in 2010 , with $150 \mathrm{~g}$ of fish being sufficient to meet more than half of an adult's daily protein need [2]. In 2012, 136.2 Mt of food fish was utilised for human consumption with an extra 21.7 Mt used for non-food uses, such as fish oil and fish feed used in aquaculture [2].

Global aquaculture (including food fish and aquatic plants) attained an industry value of US $\$ 144.4$ billion in 2012 and produced 66.6 million tonnes of farmed food fish, with farmed finfish accounting for two-thirds of the production [2].

\section{Role of Integrated Multi-trophic Aquaculture (IMTA)}

IMTA is one of the most scientifically promoted methods of removing wastes from fish farms and has been used by Asian countries for centuries. It is now gaining importance as a method to reduce the ill-effects of fish farms (including inland and marine aquaculture) especially the discharge of inorganic nitrogen that is responsible for water eutrophication. The basic concept of IMTA involves two levels: the first trophic level involves species such as Salmon or Trout (usually a carnivorous species). This species is the primary product being cultivated and is generally fed with fish processing wastes or fish oil. The second level comprises of inorganic extractive species (such as seaweed) and organic 
extractive species (such as shellfish). The nutrient rich waste that is discharged by the fish farms is sequestered by these extractive species. The dissolved nutrients (containing nitrogenous compounds and phosphates) are absorbed by the inorganic extractive species (aquatic plants including seaweed). The floating and suspended particulate matter released is eaten by organic extractive species such as mussels, sea urchins and sea cucumbers [4], [5].

\section{Requirement for Advanced Biofuels Such as Sourced from Seaweed}

On the $24^{\text {th }}$ February 2015 , a press release from the Environment Committee of the European Parliament concluded that biofuels from seaweed or certain types of wastes should contribute at least 1.25 per cent of energy consumed in transport by the year 2020 [6]. Biofuels from seaweed is an emerging area of research for both liquid and gaseous biofuels. It could not be said that there is any consensus on what the seaweed biofuel system would look like. What would be the species of seaweed? Would it be cast seaweed, or sub tidal seaweed? Would it be sourced from natural or cultivated stocks? Would the biofuel be liquid or gaseous? Whatever the system is, it is a massive task to generate $1.25 \%$ of energy from transport by 2020 from seaweed.

This paper presents a perspective seaweed biofuel system based on co-location of farmed fish and seaweed in an integrated multi-trophic aquaculture system. An objective is to suggest the resource of seaweed required to satisfy $1.25 \%$ of energy from transport by 2020 in the EU.

\section{FISH FARMS, SEAWEED AND GASEOUS BIOFUEL PRODUCTION}

\section{A. Salmon Production and IMTA}

Around $60 \%$ of the global salmon production comes from salmon farms with farmed Atlantic salmon dominating the farmed salmon market with a share of more than $90 \%$ and contributes more than $50 \%$ to the global salmon market with the total supply of farmed Atlantic Salmon in 2013 being 1.84 million tonnes HOG (head-on-gutted) [3], [7]. Atlantic salmon production is largely a function of seawater temperature and hence only selected coastal regions, where the water temperature is between 8 and $14{ }^{\circ} \mathrm{C}$ is considered optimal for salmon growth and production.

The main regions for production are around the coast of Norway, Scotland, Canada and Chile; in these areas certified licenses are required for farming as well as for catch production. A few studies have been carried out on bio-extraction by seaweed of carbon and nutrients excreted from fish farms.

Fig. 1 provides a concept of the proposed Fish to Fuel model. Depending on the composition (and hygiene) of the seaweed, it can be used for food and hydrocolloid production or biofuel. In some cases where the cost of fish feed is expensive, operators of salmon farms may prefer to use the produced seaweed as a major component of fish feed.

Table I gives an overview of results obtained at field scale as well as laboratory studies to determine the nutrient sequestration capacity of certain seaweeds. Various factors such as water temperature, currents, light hours, seeding and stocking density of the seaweed affect the productivity of such a system.

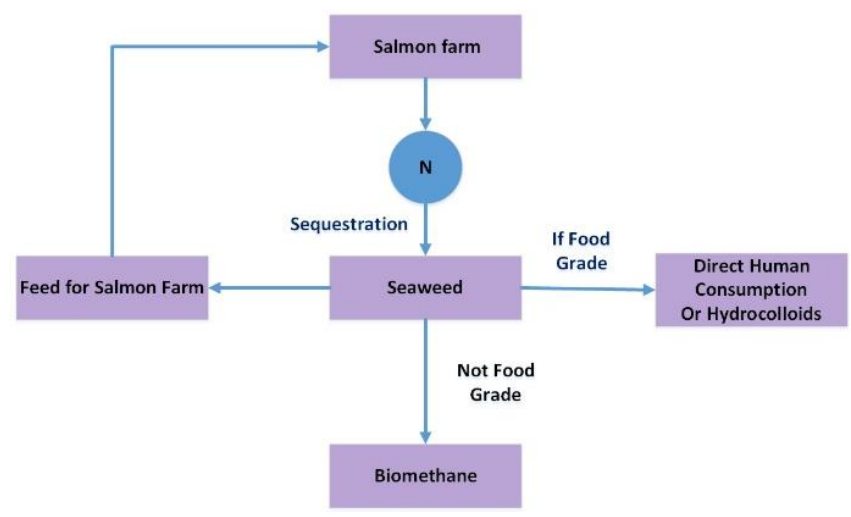

Fig. 1. Fish to fuel model.

TABLE I: SEAWEED CULTIVATIONIN INTEGRATED MULTI-TROPHIC AQUACULTURE

\begin{tabular}{|c|c|}
\hline \multicolumn{2}{|c|}{ AQUACULTURE } \\
\hline Fed Trophic level species & Seaweed cultivated \\
\hline $\begin{array}{c}\text { Sea bass } \\
\text { (Dicentrarchuslabrax), } \\
\text { Turbot (Scophthalmus } \\
\text { rhombus), Senegalese sole } \\
\text { juveniles } \\
\text { (SoleasenegalensisKaup) } \\
{[8]}\end{array}$ & $\begin{array}{l}\text { A productivity of } 23 \mathrm{~g} / \mathrm{m}^{2} / \text { day (dry } \\
\text { weight) for Gracilariavermiculophylla } \\
\text { was achieved with a nitrogen removal } \\
\text { capacity of } 1.3 \mathrm{~g} / \mathrm{m}^{2} / \text { day }\end{array}$ \\
\hline $\begin{array}{l}\text { Atlantic Salmon } \\
\text { (Salmosalar) [5] }\end{array}$ & $\begin{array}{l}\text { Mean weight ratios of } 6.7: 1 \text { and 12.9:1 } \\
\text { for Alariaesculenta and } \\
\text { Saccharinalatissima were required to } \\
\text { sequester nitrogen excreted per unit } \\
\text { weight of salmon }\end{array}$ \\
\hline $\begin{array}{c}\text { Salmon farms located near } \\
\text { Chile [9] }\end{array}$ & $\begin{array}{l}\text { A productivity of } 53 \mathrm{~g} / \mathrm{m}^{2} / \text { day (fresh } \\
\text { weight) for Gracilariachilensis was } \\
\text { achieved with a nitrogen removal } \\
\text { capacity of } 9.3 \mathrm{~g} / \mathrm{m} \text { for long line } \\
\text { cultivation }\end{array}$ \\
\hline Atlantic Salmon [10] & $\begin{array}{l}\text { Palmariapalmata and } \\
\text { Saccharinalatissima were grown at a } \\
\text { productivity of } 180 \mathrm{t} / \mathrm{ha} / \mathrm{a} \text { and } 220 \\
\text { t/ha/a and removed ca } 12 \% \text { and } 5 \% \text { of } \\
\text { nitrogen released by about } 500 \text { tonnes } \\
\text { of fish over a period of } 2 \text { years }\end{array}$ \\
\hline
\end{tabular}

\section{B. Bio-methane from Seaweed}

Bio-methane can be produced from seaweed via thermochemical or biological processes The ash content of seaweed is higher (ca 15-30\% dry matter basis) [11] than terrestrial biomass (ca 5-10\% dry matter basis) [12]. High ash content is a hindrance if used in thermal processes such as pyrolysis and gasification as ash causes fouling and slagging. Hence seaweed may be more suited to anaerobic digestion. Table II gives the bio-methane yields for a selection of seaweeds.

\section{Potential Resource of Seaweed Biofuel Associated with a Fish Farm}

The average weight of an Atlantic Salmon after two years of growth at sea is in the range 3.6-5.4 kg [19]. The amount of nitrogen excreted per kilogram growth of Salmon is $29.49 \mathrm{~g}$; this can be sequestered by $12.9 \mathrm{~kg}$ of Saccharinalatissima (wet weight) [5]. Using a methane yield of $340 \mathrm{~L} / \mathrm{kg}$ VS for $S$ latissima (Table II) the resource of seaweed biome thane from 
a $5000 \mathrm{t}$ salmon farm can be assessed as 79,216 GJ (Box 1).

TABLE II: Biome Thane Potential of Selected Seaweeds

\begin{tabular}{|c|c|}
\hline Type of seaweed & $\begin{array}{c}\text { Methane yield (L CH4/kg) Volatile } \\
\text { solids (VS) }\end{array}$ \\
\hline Ulvalactuca [13] & 271 \\
\hline Laminariadigitata [14] & 238 \\
\hline \multirow{2}{*}{ Saccharinalatissima [15], [16] } & 256 \\
\cline { 2 - 2 } & 340 \\
\hline Ascophyllumnodosum [17] & 110 \\
\hline Gracilariavermiculophylla [18] & 295 \\
\hline
\end{tabular}

BOX 1: SEAWEED BIOFUEL SySTEM ALLOWING PRODUCTION OF $1.25 \%$ oF ENERGY IN TRANSPORT IN THE EU

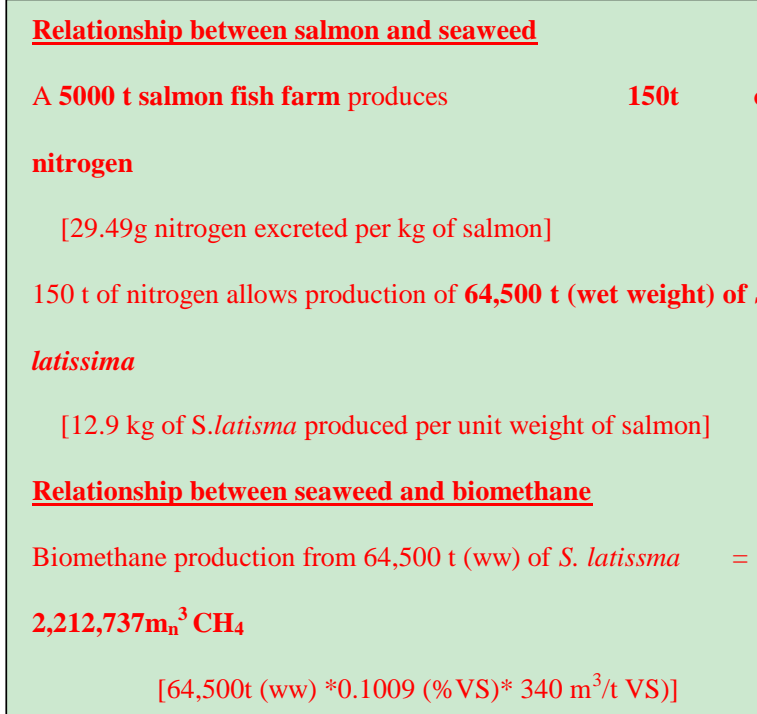

This scale is equivalent to a $1 \mathrm{MW}_{\mathrm{e}}$ digester system (at $40 \%$ electrical efficiency).

Scale of industry required to satisfy $1.25 \%$ renewable energy in transport in the $\mathbf{E U}$

Energy produced in seaweed biomethane from $5000 \mathrm{t}$ of salmon $=79,216 \mathrm{GJ}$

$\left[2,212,737 \mathrm{~m}_{\mathrm{n}}^{3} * 35.8 \mathrm{MJ} / \mathrm{m}^{3}\right]$

$1.25 \%$ of energy in transport in the EU equates to $206 \mathrm{PJ}$

2603 seaweed digesters each digesting 64,500 $\mathrm{t}$ ww of S. latissma

The model proposes that seaweed is harvested in late summer when the biome thane potential is highest. The seaweed is ensiled on shore adjacent to a coastal digester and to the natural gas grid. The biogas from the seaweed is upgraded to biome thane (methane composition of 97\% plus) and injected to the natural gas grid. In 2012 the total energy consumed in transport in the EU was of the order of $16.5 \mathrm{EJ}$ [20].

If advanced biofuels from seaweed are to satisfy $1.25 \%$ of this energy then $206 \mathrm{PJ}$ of transport biofuel is required per annum. In Box 1 it is shown that $5000 \mathrm{t}$ of salmon can generate $64,500 \mathrm{t}$ of S.latisma or $79.2 \mathrm{TJ}$ of biome thane. Based on this model, 168Mt of seaweed would need to be digested by 2020 in 2603 anaerobic digesters, each treating
$64,500 t$ ww of S.latisma per annum; at present the EU has approximately 9000 digesters operating on various substrates. The distribution system would be the existing natural gas grid.

Thus based on this model, the EU would need 13 million tonnes of salmon associated with the production of $168 \mathrm{Mt}$ of seaweed. To put this in context the total supply of farmed Atlantic Salmon in 2013 was 1.84 million tonnes HOG (head-on-gutted). The world harvest of farmed fish was 66.6Mt in 2012 Aquaculture contributed 23.8 million tonnes of aquatic algae globally in 2012. A considerable ramping up of aquaculture is required for the EU to provide transport biofuel from seaweed.

\section{Blue Growth and Blue Carbon}

The nutrient load of the $5000 \mathrm{t}$ salmon farm is equivalent to the sewage released by a community of 37,500 people; $4 \mathrm{~kg}$ of nitrogen is excreted by an average human being per year [21]. Implementation of IMTA can have the benefits of excessive nutrient extraction/sequestration; co-production of diverse products whilst only feeding the main species (the lower trophic levels live off the waste from the fish farm); and improved amenity of coastal habitat .

IMTA promotes high productivity of seaweed as there is a constant source of nutrients supplied. Similar to carbon credits, a nutrient credit system/trading is also implemented in countries (such as Sweden) for fish farms, thus increasing the total income generated by farmed fish aquaculture [8].The release of wastewater can be taxed, such as employed in Denmark where charges of $€ 4$ per $\mathrm{kg}$ of $\mathrm{N}$ released, are in place [22]. If similar charges are imposed on salmon farms the use of IMTA can reduce the burden of such taxes. The nitrogenous wastes can be compared to valuable nutrients; nitrogen based fertilizers cost ca $€ 800 / t$ [23]. Effective use of the coastal environment through IMTA concepts is classified as blue growth. Carbon sequestration in the marine environment is termed as blue carbon and is considered as an effective sink for carbon absorption.

\section{SEAWEED: FOOD VERSUS FUEL DEBATE}

\section{A. Use of Seaweed for Food}

Irrespective of the nature and method of cultivation or harvest of seaweed, there could be a competition for the resource. Asian countries are the largest producers and largest consumers of seaweed. Unlike in the West, seaweed forms an important part of the cuisine in many Asian countries. In food circles Laminaria is known as kombu, Undaria is known as wakame, Porphyrais known as Nori Kombu, Wakame and Nori are sold at US\$ 2,800/dry tonne, US\$ 6,900/dry tonne and US\$ $16,800 /$ dry tonne respectively[1].There is an increasing market in Europe for seaweed as food.

\section{B. Use of Seaweed for Industrial Applications}

Hydrocolloids from seaweed are a suitable alternative to synthetic gums, stabilisers, thickeners and gelling agents. Hydrocollids include for gelatin, xanthan, pectin, carboxy methyl cellulose, carrageenan, alginate, agar and guar; these are considered high value speciality chemicals. These are used in food products and pharmaceutical applications. 
Seaweeds have an asset value in industrial applications. The world hydrocolloid market is expected to reach annual sales of US\$ 7911 million by 2019 [24]. The hydrocolloid market is a competitor to seaweed biofuels.

\section{Use of Waste Derived Seaweed as Fish Feed}

Seaweed that is grown using waste streams from integrated multi trophic aquaculture is a suitable feedstock for biofuel, as it does not directly compete with natural or farmed resources. Its primary function is to sequester nutrients from the waste secreted from fish farms and as such may not be seen as a high value food for human consumption commanding prices such as for Kombu (laminaria) of US\$ 2,800/dry tonne.

Fish feed and fish oil high in omega- 3 fatty acids, are the preferred choice of feed for fish farms, especially for species such as salmon and trout. The prices of fishmeal and fish oil have seen an increase [25]. Alternative sources of fish food such as soymeal and corn meal have been used. Micro and macro-algae (seaweed) are also suggested to supplement the nutrient requirement of fish farms. Certain species of sea urchins, abalones and fish utilise seaweed as their source of food during the early stages of growth. Hence the seaweed produced from fish farms may partly be used as feed for the organisms being cultivated.

\section{Further Research}

Much research is required on seaweed and biofuel production from seaweed. Technical and economic feasibility of offshore and onshore based IMTA systems is required. Offshore systems will require new infrastructure to be built (such as structural rigs); onshore systems require land. Detailed composition of the seaweed produced using IMTA is necessary. Life cycle analysis including for sustainability analysis for seaweed biofuel is required to justify the benefits of this third generation biofuel as compared to first (food crops) and second (lignocellulosic biomass) generation biofuel systems. Biorefinery systems, which include for biofuel production from the residues obtained after alginate and other high value products have been extracted, should be assessed.

Moreover the sustainability of salmon farms may also be assessed. The production of farmed finfish is associated with many problems such as disease outbreak; that can also affect the wild species present in the natural water. Use of antibiotics, chemicals and steroids are damaging to the ecosystem, as are the high levels of nutrient discharge from the waste from fish farms [26], [27]. Regulations will come into force, which will ultimately improve on the shortcomings of aquaculture and may lead to IMTA and seaweed production becoming standard at fish farms [28], [29].

\section{CONCLUSION}

Seaweed is a food and a versatile raw material. If advanced biofuels from seaweed are to satisfy $1.25 \%$ of energy in transport, the EU would need 13 million tonnes of salmon, generating $168 \mathrm{Mt}$ of seaweed that would need 2603 anaerobic digesters. The world harvest of farmed fish was 66.6Mt in 2012; aquaculture contributed ca. 23 million tonnes of seaweed in 2012 .Natural stocks of seaweed cannot be involved in this increasing demand for seaweed IMTA can improve the sustainability of fish farms, clean the waters of excess nutrients and supply seaweed as raw material for industry and as biofuel.

\section{REFERENCES}

[1] FAO. (2003). A Guide to the seaweed industry. Food and Organization of the United Nations. [Online]. Available: http://www.fao.org/docrep/006/y4765e/y4765e04.htm

[2] FAO. (2014). The state of world fisheries and aquaculture. Food and Agriculture Organisation of the United Nations. [Online]. Available: http://www.fao.org/3/a-i3720e/index.html

[3] Marine Harvest Ireland. (2014). Salmon Farming Industry Handbook. [Online]. Available: http://www.marineharvestireland.com/globalassets/investors/handboo k/handbook-2014.pdf

[4] P. Chávez-Crooker and J. Obreque-Contreras, "Bioremediation of aquaculture wastes," Current Opinion in Biotechnology, vol. 21, pp. 313-317, June 2010.

[5] G. K. Reid et al.,"Weight ratios of the kelps, Alaria esculenta and Saccharina latissima, required to sequester dissolved inorganic nutrients and supply oxygen for Atlantic salmon, Salmo salar, in integrated multi-trophic aquaculture systems," Aquaculture, vol. 408-409, pp. 34-46, September 2013.

[6] E. Parliament. (2015). Environment committee backs switchover to advanced biofuels. European Parliament. [Online]. Available: http://www.europarl.europa.eu/news/en/news-room/content/2015022 3IPR24714/html/Environment-Committee-backs-switchover-to-adva nced-biofuels

[7] A. Bergheim, A. Drengstig, Y. Ulgenes, and S. Fivelstad, "Production of Atlantic salmon smolts in Europe - Current characteristics and future trends," Aquacultural Engineering, vol. 41, pp. 46-52, September 2009

[8] M. H. Abreu, R. Pereira, C. Yarish, A. H. Buschmann, and I. Sousa-Pinto, "IMTA with Gracilaria vermiculophylla: Productivity and nutrient removal performance of the seaweed in a land-based pilot scale system," Aquaculture, vol. 312, pp. 77-87, February 2011.

[9] M. H. Abreu et al., "Traditional vs. integrated multi-trophic Aquaculture of gracilaria chilensis C. J. Bird, J. McLachlan \& E. C. Oliveira: Productivity and physiological performance," Aquaculture, vol. 293, pp. 211-220, August 2009.

[10] J. C. Sanderson, M. J. Dring, K. Davidson, and M. S. Kelly, "Culture, yield and bioremediation potential of palmaria palmata (linnaeus) weber \& mohr and saccharina latissima (Linnaeus) C. E. Lane, C. Mayes, Druehl \& G. W. Saunders adjacent to fish farm cages in northwest Scotland," Aquaculture, vol. 354-355, pp. 128-135, July 2012.

[11] E. Allen, D. Wall, C. Herrmann, A. Xia, and J. D. Murphy, "What is the gross energy yield of third generation gaseous biofuel sourced from seaweed?" Energy, vol. 81, pp. 352-360, March 2015.

[12] C. Herrmann, M. Heiermann, and C. Idler, "Effects of ensiling, silage additives and storage period on methane formation of biogas crops," Bioresource Technology, vol. 102, pp. 5153-5161, 2011.

[13] A. Bruhn et al., "Bioenergy potential of Ulva lactuca: Biomass yield, methane production and combustion," Bioresource Technology, vol. 102, pp. 2595-2604, February 2011

[14] J. M. M. Adams, T. A. Toop, I. S. Donnison, and J. A. Gallagher, "Seasonal variation in Laminaria digitata and its impact on biochemical conversion routes to biofuels," Bioresource Technology, vol. 102, pp. 9976-9984, November 2011.

[15] G. Jard, H. Marfaing, H. Carrère, J. P. Delgenes, J. P. Steyer, C. Dumas, "French Brittany macroalgae screening: Composition and methane potential for potential alternative sources of energy and products," Bioresource Technology, vol. 144, pp. 492-498, September 2013.

[16] H. B. Nielsen and S. Heiske, "Anaerobic digestion of macroalgae: Methane potentials, pre-treatment, inhibition and co-digestion," Water Sci. Technol, vol. 64, pp. 1723-1729, October 2011.

[17] J. F. Hanssen, M. Indergaard, K. Østgaard, O. A. Bævre, T. A. Pedersen, and A. Jensen, "Anaerobic digestion of Laminaria spp. and Ascophyllum nodosum and application of end products," Biomass, vol. 14, pp. 1-13, 1987.

[18] J. V. Oliveira, M. M. Alves, and J. C. Costa, "Design of experiments to assess pre-treatment and co-digestion strategies that optimize biogas production from macroalgae Gracilariavermiculophylla," Bioresource Technology, vol. 162, pp. 323-330, June 2014. 
[19] NOAA Fisheries. (2009). Atlantic salmon (Salmo salar). National Oceanic and Atmospheric Administration. [Online]. Available: http://www.nmfs.noaa.gov/pr/species/fish/atlantic-salmon.html

[20] EEA. (December 2014). Transport energy consumption. European Environment Agency. [Online]. Available: http://www.eea.europa.eu/data-and-maps/daviz/transport-energy-cons umption-eea\#tab-chart_1

[21] I. Caldwell and A. Rosemarin. (February 2015). Human urine and faeces as a fertilizer. GRID-Arendal and Stockholm Environment Institute. [Online].

Available: http://www.grida.no/publications/et/ep5/page/2823.aspx

[22] J. V. Wagenen, M. L. Pape, and I. Angelidaki, "Characterization of nutrient removal and microalgal biomass production on an industrial waste-stream by application of the Deceleration-stat technique," Water Research, vol. 75, pp. 301-311, May 2015.

[23] Teagasc. (February 2015). Why plan your fertiliser? Teagasc: Agriculture and Food Development Authority. [Online]. Available: http://www.teagasc.ie/environment/nitrates/fertiliser_planning.asp

[24] Hydrocolloids Market. (2014). Markets and Markets: United States of America. [Online]. Available: http://www.marketsandmarkets.com/PressReleases/hydrocolloid.asp

[25] A. J. P. Nunes, M. V. C. Sá, C. L. Browdy, and M. Vazquez-Anon, "Practical supplementation of shrimp and fish feeds with crystalline amino acids," Aquaculture, vol. 431, pp. 20-27, July 2014.

[26] A. Falco, A. Martinez-Lopez, J. P. Coll, and A. Estepa, "17 - The potential for antimicrobial peptides to improve fish health in aquaculture," Infectious Disease in Aquaculture: Woodhead Publishing, pp. 457-79, 2012.

[27] S. Liu et al., "Steroids in marine aquaculture farms surrounding Hailing Island, South China: Occurrence, bioconcentration, an human dietary exposure," Science of the Total Environment, vol. 502, pp. 400-407, January 2015.

[28] L. Mulazzani and G. Malorgio, "Is there coherence in the European Union's strategy to guarantee the supply of fish products from abroad?" Marine Policy, vol. 52, pp. 1-10, February 2015.

[29] R. Willmann, K. Cochrane, and W. Emerson, "7 - FAO's ecolabelling guidelines for marine capture fisheries: An international standard," Innovations in Food Labelling: Woodhead Publishing, pp. 94-116, 2010.

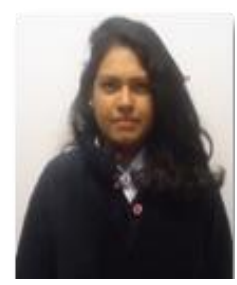

Amita Jacob is currently pursuing her $\mathrm{PhD}$ in energy engineering at University College Cork, Ireland. She received her bachelors degree from the Department of Chemical Engineering from R.V. College of Engineering, Bangalore, India. Her research interests include biohydrogen and biomethane from seaweed, carbon capture using micro-algae, biological methanation.

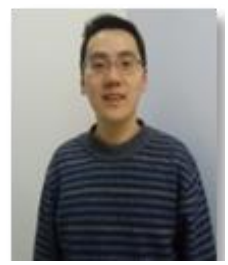

Ao Xia is currently working as a post-doctora researcher in the Environmental Research Institute (ERI) on fermentative hydrogen and methane production from algae biomass. He graduated in 2008 with a BE and completed his $\mathrm{PhD}$ research in 2013 in energy engineering from Zhejiang University (ZJU), China. In 2013 he was awarded the Chu Kochen Scholarship for the highest honours (top $0.1 \%$ ) at
ZJU, and a scholarship for Outstanding Doctoral Dissertation at ZJU. He has 29 papers in peer-reviewed journals (23 published; 6 in review) and 5 keynote/invited lectures in international conferences. He serves as a referee on peer-reviewed journals (Bioresource Technology, Energy, Journal of Cleaner Production and Energy Conversion and Management) and international conferences (International Conference on Applied Energy).

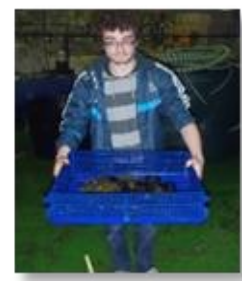

Daryl Gunning has an MSc in biodiversity and conservation (2010) and an MSc in sustainable aquaculture and inshore fisheries (2012). Since 2013 he has been studying for an industry based, IRC funded $\mathrm{PhD}$ in IMTA at University College Cork, Ireland.

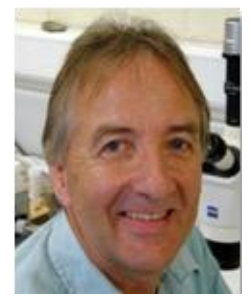

Gavin Burnell is editor in chief of Aquaculture International since 2001 and has over 60 peer reviewed publications. He is the Irish representative on the EU COST programme "EU Aquaponics Hub and regularly reviews shellfishery reports for the Marine Stewardship Council. His current research interests include marine aquaponics, integrated multi-trophic aquaculture and an ecosystem approach to aquaculture.

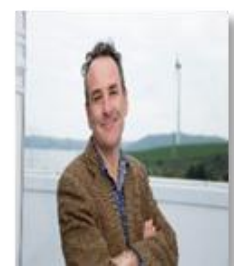

Jerry D. Murphy is professor of bioenergy and biofuels in UCC. He is the vice director of the Environmental Research Institute (ERI). He is the interim director of the Science Foundation Ireland (SFI) Centre MaREI. This is a $€ 35 \mathrm{M}$ centre of excellence in maritime and energy. Jerry has served at the International Energy Agency (IEA) since 2007 and has been appointed the incoming leader of IEA bioenergy task 37 (energy from biogas) for the trimester 2016 - 2018. He is an editor of the IEA commissioned book: "The Biogas Handbook: Science, Production and Applications". He is an author on a number of recent IEA publications including: Biogas from crop digestion (2011); A perspective on the potential role of biogas in smart energy grids (2014); and A perspective on algal biogas (2015). Jerry has authored over 70 peer review journal papers; according to Google Scholar this work has been cited ca. 3100 times in peer review press (H Factor 30). 